\title{
A Study on Online Shopping Scams
}

\author{
Nalini Arumugam \\ Akademi Pengajian Bahasa \\ Universiti Teknologi MARA (UiTM), Shah Alam, Malaysia \\ E-mail: nalini@uitm.edu.my
}

Faizah Mohamad

Akademi Pengajian Bahasa

Universiti Teknologi MARA (UiTM)

Shah Alam, Malaysia

Alice Shanthi

Akademi Pengajian Bahasa

Universiti Teknologi MARA (UiTM)

Seremban 3, Malaysia

Sai Dharinee

Monfort Boys Town, Gleanmarie, Shah Alam, Malaysia

Received: Sep. 13, $2021 \quad$ Accepted: Nov. 10, $2021 \quad$ Published: Nov. 30, 2021

doi:10.5296/ijssr.v10i1.19290 URL: https://doi.org/10.5296/ijssr.v10i1.19290

\begin{abstract}
Online shopping is becoming increasingly popular though there are several risks. Hence, this study investigates the language used by an international e-commerce platform customer to voice out their dissatisfaction, types of online shopping risks on the international e-commerce platform, and strategies acquired by the platform in addressing scamming issues on their site. A qualitative approach was used to analyse the data gathered from consumers' feedback and review of the product they purchased on the international e-commerce platform. Data were
\end{abstract}




\section{Macrothink}

International Journal of Social Science Research

ISSN 2327-5510 2022, Vol. 10, No. 1

analysed thematically. The study's findings revealed that delayed delivery and receiving counterfeit products were the most frequent complaints reported. The shopping risks identified were quality of product and delivery risks. Furthermore, the findings also revealed that the international e-commerce platform used negotiation, mediation, confrontation, and litigation strategies to combat scamming issues on its platform. The study concludes with recommendations.

Keywords: online shopping risks, e-commerce, negotiation and facilitation 


\section{Introduction}

Electronic commerce, famously known as e-commerce, is defined as buying and selling products, transmitting funds or data via an electronic network such as the Internet (Market Business News, 2019). Although e-commerce has been around since 1991, the data from Google Trends show that e-commerce in Malaysia appeared ten years ago and was initially dominated by customer-to-customer businesses such as Lelong and Fashion Valet. In 2012, e-commerce started to flourish in Malaysia with the birth of three famous players in the industry, namely; Zalora, Lazada and Hermo. Subsequently, in 2015, it continued to progress rapidly with the addition of new players in e-commerce such as Shopee, 11Street, and GoShop (iPrice Group, 2019). The report from Google Trends, as shown on iPrice insight, also revealed strong competition between Lazada and Shopee in 2017 and by September 2019, Shopee ranked first in monthly web visits, App Store, PlayStore, and the number of employees.

In Malaysia, the progressive development of the Internet and the comfort of being online have developed a new online shopping market environment (Lahsasna, 2018). In connection with the current waves, this development has created a modern consumerist community where the banking field uses online banking platforms as a preferred payment medium (Lahsasna, 2018). However, the Malaysia Computer Emergency Response Team (MyCERT) linked to Cyber Security Malaysia (CSM) has revealed an alarming statistic on cybercrime. It has been disclosed that since 2008, cyber fraud issues are considered the topmost number of cases reported each year. Hence, organisations involved in e-commerce, such as Shopee, have to deal with scammers taking advantage of their site to scam consumers and draw up various strategies to gain customers' trust and eradicate scammers from their platform.

One of the earliest strategies put forward by Shopee was Shopee Guarantee. In this platform, Shopee acts as the mediator where the buyers pay Shoppe for the goods they purchase, and Shopee notifies the seller regarding the purchase. Then, once Shopee receives the ordered item from the seller or supplier, Shopee sends the item to the buyer, and only after the buyer has received and reviewed the purchased item, Shopee would release the payment to the seller. Shopee Guarantee allows buyers to check the item they have received and inquire about a refund if they are not satisfied with items received, and Shopee would refund accordingly (Milo, 2016).

However, scammers are getting more innovative, and even with Shopee Guarantee, scams such as asking buyers to deal outside the platform via chat messengers and account hijacking are still on the rise today. For example, a case was reported on mStar online in which a buyer was almost scammed after purchasing a flat-screen television at an incredibly low price as he received a verification text from Shopee to verify his account. However, Shopee found the seller's account to be fake and closed it immediately within 24hours (Mohd Khaliza, 2019).

There are many types of e-commerce platforms in Malaysia. As of 2019, according to The Star Online, Shopee saw a significant gross rise of $92.7 \%$ compared to just a year ago in 2018; Shopee is further ahead compared to other competitors such as Tokopedia, Lazada, Mysale, and many more (Tan, 2019). In addition to this, Shopee is the third most visited e-commerce 
portal that replaces Lelong and surpassed Lazada as the best application on iOS Application Store and Google Play Store (Chew, 2018). With an increasing rise of online shopping scamming that is partly due to the insufficient knowledge in online security awareness, inadequate use of personal security devices (computer, laptop, mobile phone, tablet), and uncultured Malaysian mindset, consumers must be cautious in disclosing personal information (Tang, 2019).

As online fraud is facilitated by various strategies such as trickery, persuasion, impersonation, or emotional manipulation (Cross et al., 2016), the manipulation process that occurs between the scammers and victims show that victims are willing to communicate with those scammers (Chiluwa, Chiluwa, \& Ajiboye, 2017). In this situation, victims are to be blamed as victims of fraud are seen to actively violate the notion of an ideal victim as they are culpable of their own's victimization. Morad and Raman (2015) explained that some consumers are fully aware that they might be facing scamming risks when purchasing items online, such as financial risk, product experience risk, and privacy risk.

People who use the Internet frequently will need to be aware and ensure their online activities are secured (Wang, 2018). In most cases, the impact will stop the victims from stepping forward to lodge a report. Hence, the cases of scams and victims will not be settled till Internet users prevent themselves from being the next victims.

\section{Problem Statement}

In Malaysia, it is reported that Malaysia's online shopping market has reached RM5 billion in the year 2013. The Malaysia Digital Association (2012) claimed that the Malaysian Communication and Multimedia Commission had ranked online shopping as the 11th position of 15 different reasons why Malaysians access the Internet. In gaining access to online purchasing, individuals are experiencing a host of risks during online shopping (Ariff, 2014). According to Ariff (2014), it is understood that online shopping risks directly affect the purchasing power of consumers as the higher the risk in online shopping, the lower the chances of a consumer to buy or make an online purchase. Several studies in the past have looked into consumers awareness on online frauds in e-commerce (Zahari, Bilu, \& Said, 2019), risks faced by consumers in e-commerce (Morad \& Raman, 2015), and e-consumers rights in online shopping from the legal perspective (Mohd Nor, Md Salleh, Omain, \& Selamat, 2019). However, little is found in the study of the language used by consumers in communicating scamming complaints in online shopping and strategies taken by the organisation to solve these issues. Thus, this study aims to fill in the gap by looking at the language used by consumers in communicating their dissatisfaction during their online shopping experience with the international e-commerce platform, the risks observed, and Shopee's strategies to overcome these issues.

\section{Research Questions}

1) How do the international e-commerce platform customers voice their dissatisfaction and observe the online shopping risks?

2) What are the strategies used by the international e-commerce platform to overcome 
scamming issues on their platform?

\section{Conceptual Framework}

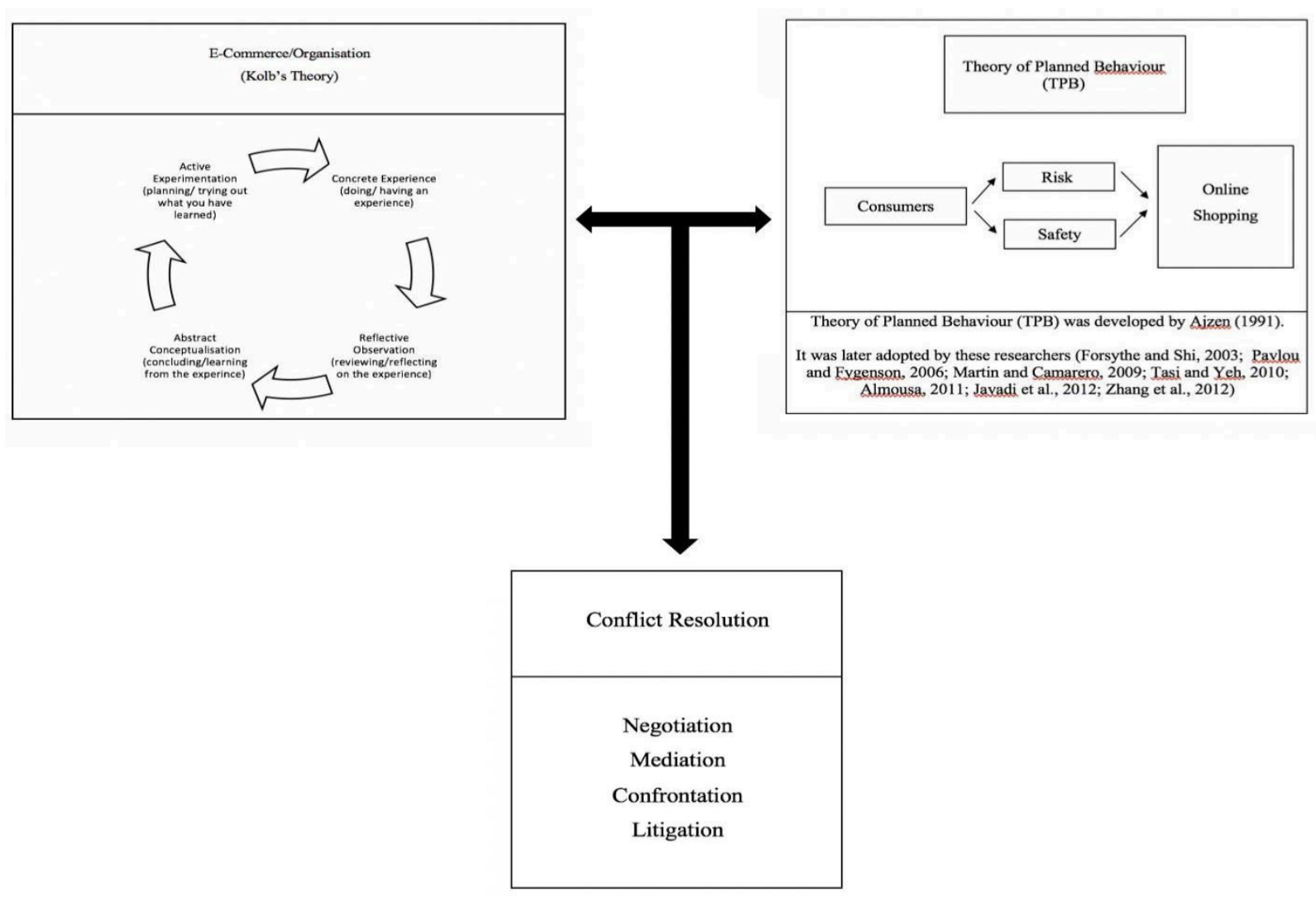

Figure 1. Conceptual framework of the study

This conceptual framework in Figure 1 draws on Kolb's Theory of Learning Styles (1984) and the Theory of Planned Behavior (TPB) which are used to address conflict resolution in solving the issues of online fraud and scams. This amalgamation of theories is expected to lead consumers to examine different conflict resolutions when facing problems in online shopping. The risk will then impact the online shopping experiences and create barriers in shopping online (Forsythe \& Shi, 2003).

Kolb's Experiential Learning Theory (ELT) is a learning theory that David created A. Kolb in 1984. This theory works on two (2) different levels, including four distinct learning styles and a four-stage learning cycle (Stice, 1987). In this, Kolb's theory possesses a holistic point of view, including experience, perception, cognition, and behavior. The experiential learning cycle includes four different stages: concrete learning, reflective observation, abstract conceptualization, and active experimentation. Accordingly, effective learning can be observed when the learner advances within the four cycles. Mc Leod (2013) stated that an individual could come into the experiential learning cycle at any stage but with a logical arrangement. 


\section{$\Delta$ Macrothink}

Martin and Camarero (2009) realised that perceived risk would take consumers to consider various signals when forming consumers' feelings and attitudes concerning a website. Several perceived risks affect the purchasing behaviour of online shopping, such as financial risk, time risk, delivery risk, product risk, information security risk, and social risk (Almousa, 2011; Javadi et al., 2012; Morad \& Raman, 2015). Ariff (2014) shared that Malaysians generally have various perceived risks, especially the level of fear.

Icek Ajzen first introduced the Theory of Planned Behaviour (TPB) in 1985. The TPB is formulated to foresee an individual's intention and purpose in involving oneself in a behaviour at a particular time and place. Simultaneously, this theory was designed to illustrate an individual's capacity to exercise self-control. In the present study, TPB concerns the individual's intention over online e-commerce, which refers conceptually to consumer's behaviour intentions and subjective norms.

\section{Methodology}

The study adopted a qualitative approach. The samples of this study are obtained using stratified random sampling from consumers' feedback and review of the product they have purchased on the international e-commerce platform. Stratified random sampling is a sampling method that divides the population into subgroups, and units are randomly selected from the subgroups (Frey, 2018). The population subgroups for this study were divided into five categories, and 38 samples of high-value content were analysed, as shown in Figure 2. Subsequently, the samples were taken verbatim, a content description analysis was done on the samples, and emerging themes were categorised into themes following the conceptual framework. Then, the themes were compared to the strategies used by The international e-commerce platform to resolve a conflict using Kolb's Theory as guided by the proposed conceptual framework of the study.

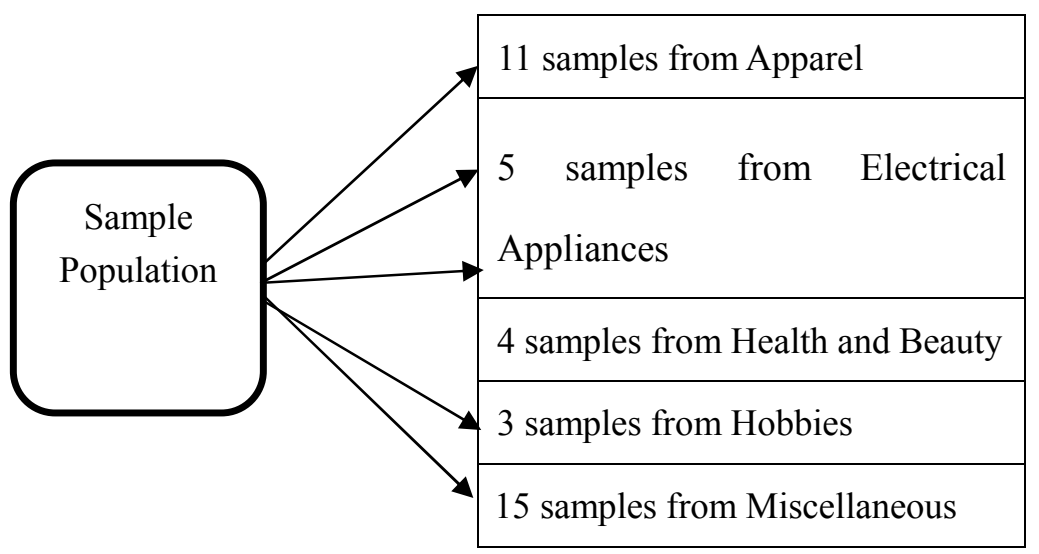

Figure 2. Population and sample of the study 


\section{Findings}

The findings will highlight the customer dissatisfaction with the international e-commerce platform and how they voiced their disappointment. This is aligned with the risks that the customers need to face in online shopping using the international e-commerce platform at their shopping platform. Therefore, the international e-commerce platform also initiated strategies to overcome the scamming issues at its shopping platform.

\subsection{Voicing Customer Dissatisfaction}

The customers voiced their dissatisfaction using words and phrases that described the negative features of the products and services. Those words and phrases were directly stated in the international e-commerce platform's feedback sections and could be viewed easily by others.

Table 1. Words or phrases used by consumers in their feedback

\begin{tabular}{lll}
\hline Words/Phrases & Quantity & Example \\
\hline Poor product quality & 11 & A2: Very poor product quality... \\
Bad packaging & 8 & A1: ... bad packaging. \\
Slow delivery & 21 & E12: very2 slow delivery... \\
Fake product & 14 & A1: The seller said $100 \%$ original... But I get a fake and the name is vaus. \\
Very disappointed & 14 & A1: Item is not original as they claim. Very disappointed. \\
Poor response & 11 & E1: No response twice when I asked ...
\end{tabular}

Table 1 shows the language used by the consumers in giving their feedback at the international e-commerce platform's website. The highest number of phrases found is 'slow delivery' and was mentioned 21 times, followed by 'fake product' and 'very disappointed' mentioned 14 times, 'poor product quality and 'poor response' mentioned 11 times, and 'bad packaging' was mentioned eight (8) times. All these descriptions through words and phrases will impact the products by giving direct information to other customers. These findings are supported by Boadi, Li, Sai and Antwi (2017), who highlighted that those direct descriptions by the customers in the websites show the connection of their dissatisfaction and their complaint on the poor product quality.

The complaints can also be seen as a judgment by the customers. This is supported by Singh and Holani (2017), who mentioned that the judgments made by customers are based on the customers' experience in online shopping and the problems they have encountered. It shows that the customers were very particular with the procedures involved in purchasing through the international e-commerce platform, and those phrases used in the complaint's sections emphasised the procedures, besides the description of the unsatisfied products received. They also explained that the experiences in online shopping, especially when the customers encountered these dissatisfactions towards the products, have led customers to write those negative words and phrases in the complaint. This is the way for the customers to convey 
their direct messages to the sellers. The customers also hope that they will address the issue to the seller and get responses.

The results clearly show that customers express their dissatisfaction through the description of the products or services. Customers described the condition of the products or services such as "bad" and "poor". These are direct words or phrases that will be viewed negatively and will impact the products.

\subsection{Risks Observed on the International E-Commerce Platform}

Customers will not be able to view the products by using e-commerce physically. It means that there are already risks in using the platforms, and they need to be well accepted by the customers. It should not be surprising to the customers when they need to encounter the delivery risks and product risks in using the international e-commerce platform.

Table 2. Online shopping risks observed on

\begin{tabular}{|c|c|c|c|}
\hline Risks & Category & Quantity & Example \\
\hline \multirow[t]{5}{*}{ Delivery Risks } & Lateness & 21 & $\begin{array}{l}\text { A4: Delivery too late. Unable to wear during my bank's } \\
\text { dinner. Really frustrated. }\end{array}$ \\
\hline & Wrong item & 2 & E14: Ordered Lavender but receive Rose... \\
\hline & Not received & 4 & A6: Never received it!! \\
\hline & Damaged & 2 & E7: ... 1 of the item broken... \\
\hline & Bad courier service & 11 & $\begin{array}{l}\text { E10: ... Pos Laju service really bad, didn't call or anything } \\
\text { and suddenly the delivery's status is unsuccessful... }\end{array}$ \\
\hline Product & Misleading & 9 & A5: Doesn't looked like advertise. \\
\hline \multirow[t]{8}{*}{ Risks } & Poor quality & 11 & A2: Very poor product quality... \\
\hline & Fake product & 14 & A1: Its not original \\
\hline & & & $\begin{array}{l}\text { B2: The power bank is a fake, there is no anti-fake Pineng } \\
\text { sticker... }\end{array}$ \\
\hline & Size & 21 & A2: Too small. \\
\hline & Smell & 3 & E14: Smell not so good \\
\hline & Colour & 7 & A10: I received wrong colour product. \\
\hline & Close to expiry date & 1 & E15: Product too close to expiry date \\
\hline & Damaged & 18 & 2 times product damage \\
\hline
\end{tabular}

There are only two main risks in shopping through The international e-commerce platform: delivery risks and product risks. The delivery risks are the risk involved in delivering the products, which is the process of shipment. So, the categories of delivery risks consist of lateness, and the wrong item received damaged product, and bad courier service. Table 2 shows the online shopping risks that the customers have encountered by using The international e-commerce platform. Among all these delivery risks, it shows that the customers encountered lateness as the highest with 21 complaints, followed by bad courier 
service with 11 complaints and the lowest was the risk of not receiving the product with four (4) complaints.

Product risks involved dissatisfaction towards the products received by the customers. These risks consist of receiving a product that is misleading, poor quality, fake, unsuitable size, inappropriate smell, wrong colour, close to the expiry date, and damaged. In their research, Singh and Holani (2017) stated that these are among the risks observed by the customers when they use the e-commerce platform. Among all these risks, the customers encountered the wrong size of products as the highest with 21 complaints, followed by receiving damaged products with 18 complaints, and the lowest was receiving fake products with 14 complaints.

The results show that the customers faced those risks in e-commerce when they purchased the international e-commerce platform. However, even though they realised that these are the risks they would probably encounter, the process of purchasing still occurred. So, the customers use the platform provided to give feedback and voice out their complaints. The international e-commerce platform itself has provided this platform as a way to communicate with the customers. Hence, those dissatisfactions and bad experiences were able to be expressed in complaints. This standard process is a typical experience in e-commerce, as $\mathrm{Wu}$ and $\mathrm{Ke}$ (2015) mentioned in their articles. So, customers should be aware of those risks and be extra alert with any disappointment they encounter. Furthermore, The international e-commerce platform also has its initiative to handle customers' disappointments. Among these initiatives is applying some negotiation strategies to tackle the issue from prolonging and hoping that they will gain customers' trust.

\subsection{Strategies Solving the International E-Commerce Platform Scamming Issues}

The international e-commerce platform has taken steps to handle the issues faced by the customers. The complaints from the customers highlight those issues. This can be identified through the words and phrases used to express contentment. However, these disappointments are the risks that the customers have already observed. Therefore, to create a better environment through The international e-commerce platform, strategies taken by the international e-commerce platform consist of negotiation strategies. They are mediation, compromising, confrontation and litigation.

Table 3. Strategies by The international e-commerce platform in combating online shopping scams

\begin{tabular}{lll}
\hline Kolb's Process & Negotiation Strategies & Shopee Strategies \\
\hline Concrete Experience & Mediation & The international e-commerce platform Guarantee \\
Reflective Observation & Compromising & Preferred Seller system \\
Abstract Conceptualization & Confrontation & Product review and Refund system \\
Active Experimentation & Litigation & Lodging police report and closing scam seller's \\
& & profile within 24 hours \\
\hline
\end{tabular}


The international e-commerce platform introduced the international e-commerce platform Guarantee system to protect buyers from scammers and gain consumers' trust. The international e-commerce platform guarantee acts as a mediator between buyers and sellers in which buyers make payment for their purchase to The international e-commerce platform, and the payment is released to sellers only after the buyers have received the product (Milo, 2016). This mediation strategy initiated by a year after they launched their online shopping site is a result of experiencing numerous reports on scamming activities.

The international e-commerce platform is faced with scammers setting up fake profiles and disguising themselves as sellers. As a compromising strategy, The international e-commerce platform has set up a 'Preferred Seller' system in which sellers on The international e-commerce platform are automatically bound to the seller penalty point system. The international e-commerce platform's team manages this system, and points will be added or deducted to a seller account based on their performance in which one of the violations is the keyword 'spam' found in the seller's product review, which will lead to a deduction of two penalty points to the seller account (Shopee, 2019).

The international e-commerce platform comprehended both experience and reflection on scamming issues to protect their site from scammers further. In this conceptualising process, the international e-commerce platform used a confrontation strategy in which buyers were required to click on 'order received' if they are satisfied with the purchased product or click on 'return/refund' along with a photo of the product and the reason why the buyer is asking for a refund (Shopee, 2019). This strategy is considered a win-win negotiation strategy as buyers will get their money back or get their product replaced, and sellers are given clear evidence as to why the international e-commerce platform does not pay them.

The international e-commerce platform does active experimentation in which the organisation reflects on the experience and devises an immediate action for the present problem (Owen, Brooks, \& Curnin, 2018). In this scenario, cases that involve financial risks and hacking into buyers account to release payment are taken seriously by The international e-commerce platform. After confirming that the seller's account is fake, it will be closed immediately within 24hours after the report was made (Mohd Khaliza, 2019).

Risks in using e-commerce are well observed. However, the customers will still be interested in using the international e-commerce platform as one of the e-commerce platforms. They will express their disappointment through those words and phrases written in the complaints section. So, these strategies are essential as tools for the international e-commerce platform to make sure that they can handle the issues.

\section{Discussions}

This study highlighted the common scenario between consumers and scammers of online shopping using an e-commerce database, The international e-commerce platform. As has been highlighted by Kolb's Experiential Learning Theory, consumers and organisations managed to experience the four (4) stages of these experiences from online shopping as observed from the findings. The Theory of Planned Behaviour (TPB) further highlights the 
consumers' behaviour when voicing their dissatisfaction with facing the risks of online shopping.

In the present, Kolb's Theory (1984) consists of concrete experience, reflective observation, abstract conceptualisation, and active experimentation. The international e-commerce platform as an organisation has substantial experience with fraud and scams while consumers shop online. Here, the goal is for the international e-commerce platform to experience to learn from these experiences. In the second stage, with the reflective observation, The international e-commerce platform reflects on the experience of the consumers before making any solutions and judgments when encountering consumers' fraud and risks matter. Then, an abstract conceptualization comes where the international e-commerce platform gives ideas by identifying the issues and recurring problems during customers' fraud experience. This helps in learning by identifying solutions for customers. In the final stage, The international e-commerce platform applies these experiences of customers' feedback and problems on fraud and scams to another situation. Here, the goal for The international e-commerce platform is to find and discovers ways to improve the online shopping platform.

In relation to our findings, the behavioural intention of the consumers indicates their attitude towards the risks as observed during online shopping. Further, customers' behaviour from the responses given when encountering problems related to scams and fraud can be seen from our findings. In Theory of Planned Behaviour (TPB), we can see various risks consumers have encountered during online shopping experience from fraud and scams. Here, consumers' actions on encountering product risks, delivery risks, and many others show the relations between the outcomes to consumers' perceived behaviours during fraud and scams.

In this connection, parties need to find a peaceful solution in order to solve problems among them. These disputes arise out of consumers' dissatisfaction and online risks, as shown in our findings. Negotiation, mediation, confrontation and litigation are resolutions used to resolve these issues of online shopping. Accordingly, Kolb's Experiential Learning Theory (1948) and Theory of Planned Behaviour (TPB) encourage the international e-commerce platform and consumers to find conflict resolution in encountering issues of online shopping and in this situation, issues on fraud and scams.

\section{Conclusion}

In conclusion, as has been highlighted by the findings and conceptual framework of these studies, there is a clear relationship between the risks of online shopping scams and solutions in conflict resolutions. The risk of online shopping scams is detrimental to both consumers of sellers and buyers as well as the organisation. All things considered, this study could create awareness among customers of the international e-commerce platform while at the same time minimising the potential risk of scams and fraud through online shopping.

\section{References}

Almousa, M. (2011). Perceived Risk in Apparel Online Shopping: A Multi-Dimensional Perspective. Canadian Social Science, 7(2), 23-31. 
Ajzen, I. (1991). The Theory of Planned Behavior. Organizational Behavior and Human Decision Process, 50, 171-211. https://doi.org/10.1016/0749-5978(91)90020-T

Aniello, S., \& Caneppele, S. (2018). Selling stolen goods on the online markets: An $\begin{array}{llll}\text { explorative } \quad \text { study. } & \text { Global } & \text { 42-62. }\end{array}$ https://doi.org/10.1080/17440572.2017.1418333

Ariff, M. S. M., Sylvester, M., Zakuan, N., Ismail, K., \& Ali, K. M. (2014). Consumer perceived risk, attitude and online shopping behaviour; empirical evidence from Malaysia (Vol. 58, No. 1, p. 012007). In IOP Conference Series: Materials Science and Engineering. IOP Publishing. https://doi.org/10.1088/1757-899X/58/1/012007

Bernama. (2013). 2014 Budget: 25 mill internet users by 2015 on. New Straits Times. Retrieved November 11, 2013, from http://www.nst.com.my/latest/font-color-red-2014-budget-font-25-mill-internet-users-by-201 $5-1.384975$

Bernama. (2019, August 13). Cyber scams top the list every year. The News Straits Times. Retrieved from https://www.nst.com.my/news/nation/2019/08/512452/cyber-scams-top-list-every-year

Boadi, P. O., Li, G., Sai, A. A., \& Antwi, P. (2017, September). A Critique of the Impact of Consumer Dissatisfaction. In International Conference on Transformations and Innovations in Management (ICTIM 2017). Atlantis Press. https://doi.org/10.2991/ictim-17.2017.44

Channel News Asia. (2019). Singapore: Nearly 100 reports of scams involving fake Lazada, Shopee lucky draws: Police. Retrieved from https://www.channelnewsasia.com/news/singapore/90-reports-of-scams-fake-lazada-shoppeelucky-draws-grab-razer-11899774

Chew, J. (2018). Who leads e-commerce in Malaysia? Lazada or Shopee? e27. Retrieved from https://e27.co/leads-e-commerce-malaysia-lazada-shopee-20180321/

Chiluwa, I. M., Chiluwa, I., \& Ajiboye, E. (2017). Online Deception: A Discourse Study of Email Business Scams.

Cross, C., Richards, K., \& Smith, R. G. (2016). Improving responses to online fraud victims: An examination of reporting and support.

Cyber scams top the list every year. (2019, August 13). The News Straits Times. Retrieved from https://www.nst.com.my/news/nation/2019/08/512452/cyber-scams-top-list- every year

Forsythe, S. M., \& Shi, B. (2003). Consumer patronage and risk perceptions in Internet shopping. Journal of Business Research, 56(11), 867-875. https://doi.org/10.1016/S0148-2963(01)00273-9

Frey, B. (2018). Stratified Random Sampling. The SAGE Encyclopedia of Educational Research, Measurement and Evaluation. https://doi.org/10.4135/9781506326139.n671

Gillespie, A. A., \& Magor, S. (2019, October). Tackling online fraud. In ERA Forum (pp. 
1-16). Springer Berlin Heidelberg.

Iowa State University Library. (2019, November 12). Research Methodologies Guide. Retrieved from https://instr.iastate.libguides.com/c.php?g=49332\&p=318069

iPrice Group. (2019). The Map of E-commerce in Malaysia. Retrieved November 21, 2019, from https://iprice.my/insights/mapofecommerce/en/

Javadi, M., Dolatabadi, H., Nourbakhsh, M., Poursaeedi, A., \& Asadollahi, A. (2012). An Analysis of Factors Affecting on Online Shopping Behaviour of consumers. International Journal of Marketing Studies, 4(5), 81-98. https://doi.org/10.5539/ijms.v4n5p81

Kolb, D. (1984). Experiential learning: Experience as the source of learning and development. Englewood Cliffs, New Jersey: Prentice Hall.

Lahsasna, A. (2018). Financial Consumer in Malaysia: Regulators Efforts and Measurements for Consumer Protection (pp. 317-331). In An International Comparison of Financial Consumer Protection. Springer, Singapore. https://doi.org/10.1007/978-981-10-8441-6_11

Malaysia Digital Association. (2012). Malaysia Website Ranking for February 2012. Retrieved March, 15, 2013, from http://www.digital.org.my/pdf/MDA-EM

Market Business News. (2019). What is E-commerce? Definition and examples. Retrieved November 21, 2019, from https://marketbusinessnews.com/financial-glossary/e- commerce/

Martin, S. S., \& Camarero, C. (2009). How perceived risk affects online buying. Online Information Review, 33(4), 629-654. https://doi.org/10.1108/14684520910985657

McLeod, J. (2013). An introduction to counselling (5th ed., pp. 6-7). McGraw-Hill Education (UK).

Milo, E. (2016, February 16). Shopee Malaysia prevents scams with Shopee Guarantee. EC Insider. Retrieved from https://news.ecinsider.my/2016/02/shopee-malaysia-prevents-scams-with-shopee-guarantee.h tml

Mohd Khalizan, M., I. (2019). "Akaun penipu ditutup dalam masa 24 jam” - Shopee berterima kasih pelanggan bongkar penipuan. Media Star Online. Received from https://www.mstar.com.my/lokal/viral/2019/02/27/follow-up-scammer-shopee/\#U1xMjpcHgo BAIEKP.99

Morad, M., \& Raman, S. (2015). The Risk Faced by Consumers in E-Retailing. International Journal of Accounting \& Business Management, 3(1), 292-299. https://doi.org/10.24924/ijabm/2015.04/v3.iss1/292.299

Owen, C., Brooks, B., \& Curnin, S. (2018). Enhancing Learning in Emergency Services Organisational Work. Australian Journal of Public Administration, 77(4), 715-728. https://doi.org/10.1111/1467-8500.12309

Saieed, Z. (2019, October 18). E-Commerce Platform Shopee Confident of Sustaining Strong 
Growth.

The

Star

Online.

Retrieved

from

https://www.thestar.com.my/business/business-news/2019/10/18/e-commerce-platform-shope e-confident-of-sustaining-strong-growth

Shopee. (2019, June 4). [Refund Request] When and how can I apply for a return refund? Retrieved December 10, 2019, from https://help.shopee.com.my/my/s/article/When-and-how-can-I-apply-for-a-return-154297203 1358

Shopee. (2019, June 7). [Seller Performance] What is Shopee's Seller Penalty Points system? Retrieved December 10, 2019, from https://help.shopee.com.my/my/s/article/What-is-Shopee-s-Seller-Penalty-Points-system-154 2971633226

Singh, A., \& Holani, U. (2017). Factors affecting Complainer's Satisfaction towards Online Shopping in India. Vimarsh, 9.

Stice, J. E. (1987). Using Kolb's Learning Cycle to Improve Student Learning. Engineering Education, 77(5), 291-296.

Tan, Z. (2019, August 22). iPrice report has Shopee down as the most popular shopping platform in Southeast Asia. Kr-Asia. Retrieved from $\mathrm{https}$ ://kr-asia.com/iprice-report-has-shopee-down-as-the-most-popular-shopping-platform-in -Southeast-Asia

Tang, A. (2019, November 10). Shoppers warned of 11.11 scams. The Star Online. Retrieved from https://www.thestar.com.my/news/nation/2019/11/10/shoppers-warned-of-1111- scams

Wang, C. (2018). Online News Coverage About Fraud and Self-Defensive Behavior in China. Wu, W. Y., \& Ke, C. C. (2015). An online shopping behavior model integrating personality traits, perceived risk, and technology acceptance. Social Behavior and Personality: An International Journal, 43(1), 85-97. https://doi.org/10.2224/sbp.2015.43.1.85

Zahari, A. I., Bilu, R., \& Said, J. (2019). The Role of Familiarity, Trust and Awareness Towards Online Fraud. Journal of Research and Opinion, 6(9), 2470-2480.

\section{Copyrights}

Copyright for this article is retained by the author(s), with first publication rights granted to the journal.

This is an open-access article distributed under the terms and conditions of the Creative Commons Attribution license (http://creativecommons.org/licenses/by/4.0/). 